\title{
PROTON DRIVER POWER SUPPLY SYSTEM
}

\author{
C. Jach, D. Wolff, FNAL, Batavia, IL 60510, USA
}

\section{Abstract}

This paper describes magnet power supply system for a proposed Proton Driver at Fermilab. The magnet power supply system consists of resonant dipole/quadrupole power supply system, quadrupole tracking, dipole correction (horizontal and vertical) and sextupole power supply systems. This paper also describes preliminary design of the power distribution system supplying $13.8 \mathrm{kV}$ power to all Proton Driver electrical systems.

$$
I(t)=I_{d c}-I_{a c} \cos (2 \pi 15 t)+0.125 I_{a c} \sin (2 \pi 30 t)
$$

\section{INTRODUCTION}

Power supply system for dipoles and quadrupoles is designed to provide current to the magnets of the form:

Adding second harmonic $(30 \mathrm{~Hz})$ to the fundamental of the magnet current reduces $\mathrm{dB} / \mathrm{dt}$ in the magnets during acceleration. A $12.5 \%$ second harmonic component results in $25 \%$ reduction of $\mathrm{dB} / \mathrm{dt}$.

Since all magnets are designed to operate at $16 \mathrm{GeV}$, all magnet power supply system components interfacing Proton Driver magnets must be designed to operate at 16 $\mathrm{GeV}$. These include interconnecting bus, terminals, LCW water system, bucking chokes, power supplies, controls and regulation systems. Infrastructure (service buildings, equipment pads) and $13.8 \mathrm{kV}$ power distribution system are also designed to accommodate $16 \mathrm{GeV}$ configuration. Energy storage devices (resonant cell chokes and capacitors) for the dipole/quadrupole resonant network are designed to operate at $12 \mathrm{GeV}$ and can be fully utilized in $16 \mathrm{GeV}$ configuration.

\section{SUBSYSTEMS}

\subsection{Dipole/Quadrupole Resonant Power Supply Subsystem}

The choice of magnet resonant network configuration is influenced by three factors: the need to avoid drawing a large reactive power from the a.c. line, reliability, and cost.

A circuit in Figure 1 satisfies the basic requirements. The diagram shows two resonant cells near the power supply. Dipoles, quadrupoles $\mathrm{F}$ and quadrupoles D are connected in series. Power supplies are inserted in series with magnets near virtual ground of the distributed resonant circuit. Each power supply is a source of a.c. and d.c. power (similar to Fermilab Booster). Dividing the resonant system into 30 resonant cells permits notable decrease in the system voltage to ground. Equivalent cell magnet $\left(\mathrm{L}_{\mathrm{m}}\right)$, capacitor banks $\left(\mathrm{C}\right.$ and $\left.\mathrm{C}_{1}\right)$, and chokes $\left(\mathrm{L}_{\mathrm{ch}}\right.$, and $\mathrm{L}_{1}$ ), form a resonant cell with two series resonant frequencies: $15 \mathrm{~Hz}$ and $30 \mathrm{~Hz}$.

Owing to its series connection, the distributed resonance circuit provides a basic uniformity in magnets currents. It is necessary to ensure that the a.c. potentials of the corresponding points in the network attain a similar value. This is achieved by matching equivalent cell magnet inductances, close tolerances of each resonant cell components and auxiliary windings in chokes $\mathrm{L}_{\mathrm{ch}}$ connected in parallel with each other.

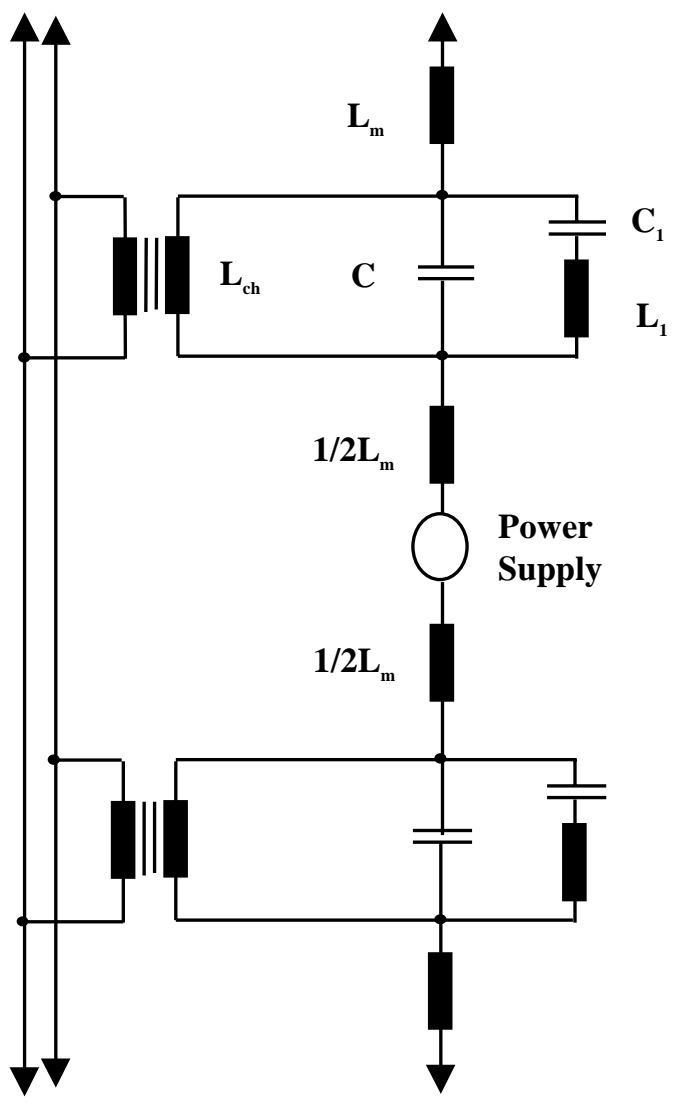

Figure 1: Dipole/Quadrupole Resonant network.

Calculations of d.c. resistances and d.c. losses have been scaled from Fermilab Booster. All system parameters will be verified when a prototype resonant cell becomes available. The dipole/quadrupole power supply subsystem parameters are shown in Table 1. 
Table 1: Dipole/Quadrupole Subsystem Parameters

\begin{tabular}{|c|c|c|}
\hline Parameter & $\begin{array}{c}12 \mathrm{GeV} \\
\text { Mode }\end{array}$ & $\begin{array}{c}16 \mathrm{GeV} \\
\text { Mode }\end{array}$ \\
\hline Irms & $3,000 \mathrm{~A}$ & $4,000 \mathrm{~A}$ \\
\hline Total a.c. voltage & $247,000 \mathrm{~V}$ & $324,000 \mathrm{~V}$ \\
\hline Total d.c. voltage & $1,500 \mathrm{~V}$ & $1,900 \mathrm{~V}$ \\
\hline Number of resonant cells & 30 & 30 \\
\hline Voltage to ground, peak & $4,400 \mathrm{~V}$ & $5,700 \mathrm{~V}$ \\
\hline Total losses & $4.1 \mathrm{MW}$ & $8.9 \mathrm{MW}$ \\
\hline Number of power supplies & 3 & 3 \\
\hline Power supply current, peak & $4,900 \mathrm{~A}$ & $6,400 \mathrm{~A}$ \\
\hline Power supply voltage, peak & $\pm 900 \mathrm{~V}$ & $\pm 1,200 \mathrm{~V}$ \\
\hline
\end{tabular}

\subsection{Quadrupole Tracking and Correction Power Supply Subsystem}

The quadrupole correction peak current requirements at given frequencies are set by the required tune compensation or tracking compensation, whichever is higher. It is assumed that only frequencies up to 7 th harmonic $(105 \mathrm{~Hz})$ will be required to provide sufficient quadrupole field gradient correction (tracking compensation and tune control). Table 2 gives quadrupole tracking and correction power supplies system requirements. Tracking correction has been calculated using dipole and quadrupole saturation curves. Tune compensation requirements are predicted values needed for tune compensation.

Table 2: Quadrupole Tracking Subsystem Requirements

\begin{tabular}{|c|c|c|c|}
\hline $\begin{array}{c}\text { Freq } \\
{[\mathrm{Hz}]}\end{array}$ & $\begin{array}{c}\text { Tracking } \\
{[ \pm \%]}\end{array}$ & $\begin{array}{c}\text { Tune } \\
{[ \pm \%]}\end{array}$ & $\begin{array}{c}\text { Requirement } \\
{[ \pm \%]}\end{array}$ \\
\hline 15 & 0.53 & 2.00 & 2.00 \\
\hline 30 & 0.36 & 0.20 & 0.36 \\
\hline 45 & 0.21 & 0.10 & 0.21 \\
\hline 60 & 0.09 & 0.10 & 0.10 \\
\hline 75 & 0.02 & 0.10 & 0.10 \\
\hline 90 & 0.03 & 0.10 & 0.10 \\
\hline 105 & 0.03 & 0.10 & 0.10 \\
\hline
\end{tabular}

Due to space requirements the quadrupole correctors are planned to be integrated in the quadrupole magnets. The estimated induced voltage from the main bus is 8.5 $\mathrm{kV}$ per quadrupole family.

The primary windings of the bucking choke are connected in series with quadrupole trim windings, while the secondary windings are connected in series with the main coils. The mutual inductance of the bucking choke must be equal in value (but opposite in sign) to the sum of mutual inductances of the quadrupole main/trim coil transformers for proper operation.

\subsection{Dipole Horizontal Correction Subsystem}

Horizontal orbit correction is accomplished using trim coils wound on the dipole magnet cores. Each dipole magnet is supplied with two sets of trim coils having an equal number of turns. They are connected in series but with opposite magnetic senses so that no net voltage is induced across them by the main coil current. The common connection point between the two trim coils is then connected together with the common points between the other trim coils as shown in Figure 2. Each trim set is driven by an independent programmable power supply. The effect of energizing a single trim set is to cause a local horizontal orbit shift without altering the beam orbit path length. Subsystem parameters are shown in Table 3 below.

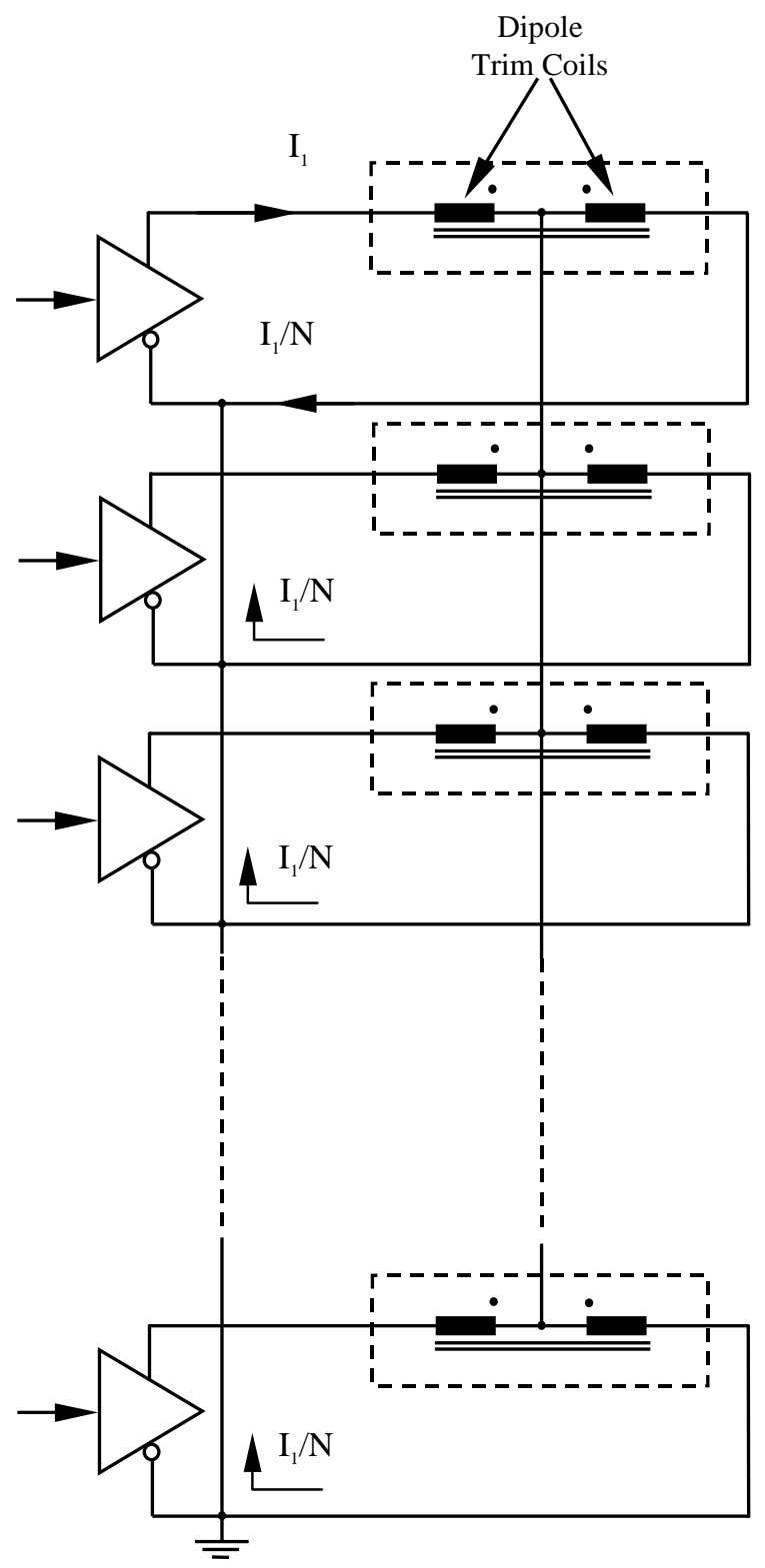

Figure 2: Dipole Horizontal Correction System Principle 
Table 3: Dipole Horizontal Correction System Parameters

\begin{tabular}{|l|c|c|}
\hline Parameter & $\begin{array}{c}12 \mathrm{GeV} \\
\text { Mode }\end{array}$ & $\begin{array}{c}16 \mathrm{GeV} \\
\text { Mode }\end{array}$ \\
\hline Irms & $210 \mathrm{~A}$ & $280 \mathrm{~A}$ \\
\hline Number of Power Supplies & 48 & 48 \\
\hline Power Supply Current, peak & $360 \mathrm{~A}$ & $480 \mathrm{~A}$ \\
\hline Power Supply Voltage, peak & $\pm 40 \mathrm{~V}$ & $\pm 50 \mathrm{~V}$ \\
\hline
\end{tabular}

\subsection{Dipole Vertical Correction Subsystem}

Separate corrector magnets situated at specific points in the ring accomplish vertical orbit correction. The vertical corrector magnets are driven with programmable power supplies similar to those used for horizontal correction. Subsystem parameters are shown in Table 4 below.

Table 4: Dipole Horizontal Correction Subsystem Parameters

\begin{tabular}{|l|c|c|}
\hline Parameter & $\begin{array}{c}12 \mathrm{GeV} \\
\text { Mode }\end{array}$ & $\begin{array}{c}16 \mathrm{GeV} \\
\text { Mode }\end{array}$ \\
\hline Irms & $230 \mathrm{~A}$ & $310 \mathrm{~A}$ \\
\hline Number of Power Supplies & 36 & 36 \\
\hline Power Supply Current, peak & $300 \mathrm{~A}$ & $400 \mathrm{~A}$ \\
\hline Power Supply Voltage, peak & $\pm 450 \mathrm{~V}$ & $\pm 600 \mathrm{~V}$ \\
\hline
\end{tabular}

\subsection{Sextupole Power Supply Subsystem}

The sextupole power supply system consists of 3 independent circuits with distributed power supplies: SF loop, SD loop, and a stray field compensation loop. Table 5a describes subsystem parameters for $12 \mathrm{GeV}$ mode of operation and Table $5 \mathrm{~b}$ gives subsystem parameters for 16 $\mathrm{GeV}$ mode of operation.

Table 5a: Sextupole Power Supply - 12 GeV Mode

\begin{tabular}{|c|c|c|c|}
\hline Circuit & SF & SD & Comp. \\
\hline $\begin{array}{c}\text { Number of } \\
\text { sextupoles per } \\
\text { circuit }\end{array}$ & 24 & 24 & \\
\hline Irms & $960 \mathrm{~A}$ & $1,400 \mathrm{~A}$ & $440 \mathrm{~A}$ \\
\hline $\begin{array}{c}\text { Induced voltage } \\
\text { per circuit, peak }\end{array}$ & $1,350 \mathrm{~V}$ & $1,900 \mathrm{~V}$ & $25 \mathrm{~V}$ \\
\hline $\begin{array}{c}\text { Number of power } \\
\text { supplies }\end{array}$ & 2 & 3 & 1 \\
\hline $\begin{array}{c}\text { Power supply } \\
\text { current, peak }\end{array}$ & $1,800 \mathrm{~A}$ & $2,700 \mathrm{~A}$ & $900 \mathrm{~A}$ \\
\hline $\begin{array}{c}\text { Power supply } \\
\text { voltage, peak }\end{array}$ & $\pm 700 \mathrm{~V}$ & $\pm 700 \mathrm{~V}$ & $\pm 30 \mathrm{~V}$ \\
\hline
\end{tabular}

Table 5b: Sextupole Power Supply - 16 GeV Mode

\begin{tabular}{|c|c|c|c|}
\hline Circuit & SF & SD & Comp. \\
\hline $\begin{array}{c}\text { Number of } \\
\text { sextupoles per } \\
\text { circuit }\end{array}$ & 24 & 24 & \\
\hline Irms & $1,300 \mathrm{~A}$ & $1,900 \mathrm{~A}$ & $600 \mathrm{~A}$ \\
\hline $\begin{array}{c}\text { Induced voltage } \\
\text { per circuit, peak }\end{array}$ & $1,800 \mathrm{~V}$ & $2,600 \mathrm{~V}$ & $33 \mathrm{~V}$ \\
\hline $\begin{array}{c}\text { Number of power } \\
\text { supplies }\end{array}$ & 2 & 3 & 1 \\
\hline $\begin{array}{c}\text { Power supply } \\
\text { current, peak }\end{array}$ & $1,800 \mathrm{~A}$ & $2,700 \mathrm{~A}$ & $900 \mathrm{~A}$ \\
\hline $\begin{array}{c}\text { Power supply } \\
\text { voltage, peak }\end{array}$ & $\pm 1,000 \mathrm{~V}$ & $\pm 1,000 \mathrm{~V}$ & $\pm 33 \mathrm{~V}$ \\
\hline
\end{tabular}

\subsection{Power Distribution Subsystem}

At this stage of the project, it is assumed that the existing site power distribution system will not able to meet Proton Driver power demand. To meet Proton Driver power requirements, a new substation as well as existing facilities will be utilized. Table 6 gives power requirements of the power distribution system. To take advantage of the existing $345 \mathrm{kV}$ equipment, the substation will be located inside existing Kautz Road Substation.

Table 6: Power Distribution Requirements

\begin{tabular}{|l|c|c|}
\hline Subsystem & $\begin{array}{r}\text { Peak } \\
\text { MVA }\end{array}$ & $\begin{array}{c}\text { RMS } \\
\text { MVA }\end{array}$ \\
\hline RF & 40.0 & 10.0 \\
\hline Dipole/Quad & 18.0 & 16.1 \\
\hline Sextupole & 11.7 & 8.5 \\
\hline Quad Correction & 5.0 & 4.4 \\
\hline Vert. Dipole & 10.0 & 8.9 \\
\hline Hor. Dipole & 0.8 & 0.7 \\
\hline Vacuum & 1.8 & 1.8 \\
\hline Conventional & 1.5 & 1.5 \\
\hline Total & 88.8 & 51.9 \\
\hline
\end{tabular}

\section{REFERENCES}

[1] http://www-bd.fnal.gov/pdriver/designreport/ch07.pdf

[2] FERMILAB-Pub-74/85 0323.000 (1974)

[3] R. Hettel, C. Jach, R. Averill, M. Baltay, S. Brennan, C. Harris, M. Horton, J, Sebek, J. Voss - The 10 $\mathrm{Hz}$ Resonant Magnet Power Supply for the SSRL $3 \mathrm{GeV}$ Injector (1991 IEEE Particle Accelerator Conference)

[4] C. Jach, A. Medvedko, Y. Fishler - Energy Storage Inductor for the Low Energy Booster Resonant Power Supply System (1993 IEEE Particle Accelerator Conference) 